\title{
Indução, análises morfológicas e ultraestruturais de calos de maracujazeiro nativo ${ }^{1}$
}

\author{
Milene Alves de Figueiredo Carvalho*2, Renato Paiva ${ }^{3}$ Raírys Cravo Herrera ${ }^{4}$, Eduardo Alves ${ }^{5}$, \\ Evaristo Mauro de Castro ${ }^{6}$, Patrícia Duarte de Oliveira Paiva ${ }^{7}$, Daiane Peixoto Vargas ${ }^{8}$ \\ http://dx.doi.org/10.1590/0034-737X201562040002
}

\begin{abstract}
RESUMO
A análise de calos que apresentem características embriogênicas é importante para posterior regeneração, in vitro, de espécies com características agronômicas desejáveis, como o maracujazeiro nativo Passiflora gibertii. Diante do exposto, objetivou-se, com este trabalho, analisar a indução de calos oriundos de explantes foliares de Passiflora gibertii N. E. Brown, bem como caracterizá-los, morfológica e ultraestruturalmente. Para obtenção de calos, folhas cotiledonares foram inoculadas, em meio de cultura, suplementado com picloram e 2,4-D, combinados com cinetina. Após 30 dias em meio de cultura, no escuro, os calos obtidos foram preparados para a visualização em microscopia eletrônica (transmissão e varredura) e microscopia de luz. Os resultados permitem afirmar que a adição de picloram e cinetina ao meio de cultura promove maior formação de calos em explantes foliares de $P$. gibertii que 2,4-D e cinetina. O regulador 2,4-D proporciona a obtenção de calos com células de formato isodiamétrico, pequenas e com pequeno espaço intercelular, sistema celular organizado e predominância de mitocôndrias de formato arredondado.

Já com a utilização do regulador de crescimento picloram, observa-se a predominância de células grandes e de formato alongado, de espaços intercelulares, de sistema celular desorganizado e de mitocôndrias de formato alongado.
\end{abstract}

Palavras-chave: calogênese, ácido 2,4-diclorofenoxiacético, picloram, Passiflora gibertii, N. E. Brown.

\section{ABSTRACT}

\section{Induction, morphologic and ultra-structural analyses of native passion fruit calluses}

Analysis of calluses with embryogenic characteristics is important for subsequent in vitro regeneration of species with desirable agronomic traits such as the Passiflora gibertii native passion fruit. In this context, the present study aimed to analyze the induction of calluses from leaf explants of Passiflora gibertii N. E. Brown, as well as their morphologic and ultra-structural characterization. Cotyledonary leaves were inoculated in culture medium containing 2,4-D and picloram in association with kinetin. After 30 days of cultivation in the dark, the obtained calluses were prepared for the visualization in electron microscope (transmission and scanning) and light microscope. The results allowed to infer that the addition of picloram and kinetin to the culture medium promotes higher callus formation in

\footnotetext{
Submetido em 05/11/2013 e aprovado em 23/05/2015

${ }^{1}$ Este trabalho é parte da dissertação de mestrado da primeira autora.

2 Embrapa Café, Brasília, Distrito Federal, Brasil. milene.carvalho@embrapa.br

Universidade Federal de Lavras, Departamento de Biologia, Lavras, Minas Gerais, Brasil. renpaiva @dbi.ufla.br

${ }^{4}$ Universidade Federal do Pará, Altamira, Pará, Brasil. rairys@ gmail.com

${ }^{5}$ Universidade Federal de Lavras, Departamento de Fitopatologia, Laboratório de Microscopia Eletrônica e Análise Ultraestrutural, Lavras, Minas Gerais, Brasil. ealves@ @ff.ufla.br

${ }^{6}$ Universidade Federal de Lavras, Departamento de Biologia, Lavras, Minas Gerais, Brasil. emcastro@ dbi.ufla.br

${ }^{7}$ Universidade Federal de Lavras, Departamento de Agricultura, Lavras, Minas Gerais, Brasil. patriciapaiva@dag.ufla.br

${ }^{8}$ Embrapa Clima Temperado, Pelotas, Rio Grande do Sul, Brasil. dvbio@ hotmail.com

*Autora para correspondência: milene.carvalho@embrapa.br
} 
cotyledonary leaf explants of $P$. gibertii than 2,4-D and kinetin. The growth regulator 2,4-D provides the formation of calluses with small isodiametric cells and small intercellular spaces, an organized cellular system and the predominance of round shaped mitochondria. Predominance of large and elongated cells with intercellular spaces, a non-organized cellular system and predominance of elongated mitochondria was observed when picloram was used.

Key words: callogenesis, 2,4-dichlorophenoxyacetic acid, picloram, Passiflora gibertii, N. E. Brown.

\section{INTRODUÇÃO}

Espécies silvestres do gênero Passiflora, como Passiflora gibertii, têm apresentado variabilidade para resistência às principais doenças do maracujazeiro $(\mathrm{Cu}-$ nha et al., 2002; Aguiar et al., 2010) e essa característica pode ser introduzida no maracujazeiro comercial.

A utilização de técnicas de cultura de tecidos, como micropropagação (Santana et al., 2011; Soares et al., 2012), hibridação somática (Silvia et al., 2005) ou transformação genética (Reis et al., 2007), dentre outras, pode contribuir para a obtenção de plantas com características agronômicas desejáveis e ter aplicação direta nos programas de melhoramento genético de Passiflora spp.

A regeneração in vitro pode seguir duas vias: a da organogênese ou a da embriogênese somática. Essas vias podem ser realizadas de forma indireta ou direta, dependendo da formação, ou não, de calos respectivamente. Especificamente, quanto ao processo de embriogênese somática in vitro, as auxinas desempenham papel essencial na indução do embrião somático, em cultura e posterior desenvolvimento desse embrião, sendo que o regulador ácido 2,4-diclorofenoxiacético (2,4-D) é um dos mais utilizados para esse propósito (Pinto et al., 2010; Pinto et al., 2011), podendo vir acompanhado de citocininas, como a cinetina. Outro regulador interessante a ser estudado é a auxina picloram (ácido 4-amino3,5,6-tricloropiridina-2-carboxílico), que promove alta indução de calos (Pacheco et al., 2012) e de embriões somáticos (Corredoira et al., 2015).

Analisar a indução de calos com características embriogênicas para posterior regeneração de plantas in vitro é, portanto, importante para a multiplicação de plantas, com características agronômicas desejáveis, de diferentes espécies de Passiflora spp. (Pinto et al., 2011; Rocha et al., 2015).

Trabalho desenvolvido com a espécie $P$. gibertii caracterizou estruturalmente a calogênese dessa espécie, com base nas diferentes colorações observadas, em meio de cultura suplementado com picloram e cinetina (Carvalho et al., 2013). Entretanto, não há, até o momento, estudo detalhado da interação entre reguladores de crescimento na indução e na análise das características estruturais de calos para a espécie em questão. Neste contexto, objetivou-se, com este trabalho, analisar a indução de calos oriundos de explantes foliares de Passiflora gibertii, bem como caracterizá-los, morfológica e ultraestruturalmente.

\section{MATERIAL E MÉTODOS}

Sementes de maracujazeiro Passiflora gibertii (acesso CPAC MJ-22-01) foram obtidas da coleção de germoplasma da Embrapa Cerrados/CPAC, Planaltina, DF. Para obtenção das plantas matrizes jovens (2 meses de idade), as sementes foram germinadas in vivo e mantidas em sala de crescimento, a $25 \pm 2^{\circ} \mathrm{C}$, irradiância de fótons de $43 \mu \mathrm{mol} \mathrm{m} \mathrm{m}^{-2} \mathrm{~s}^{-1}$ fotoperíodo de 16 horas.

Calos foram obtidos, utilizando-se folhas cotiledonares inteiras, previamente desinfestadas em câmara de fluxo laminar e imersas em solução de hipoclorito de sódio $(\mathrm{NaOCl})$, com $0,5 \%$ de cloro ativo, acrescido de Tween 20 (uma gota por $100 \mathrm{~mL}$ de hipoclorito) por dez minutos e, posteriormente, lavadas três vezes em água destilada e autoclavada.

Após desinfestação, as folhas foram excisadas em diâmetros de aproximadamente $1 \mathrm{~cm}^{2}$ e o material vegetal recebeu pequenos cortes por toda a superfície, com bisturi, sendo inoculado com a face abaxial em contato com o meio de cultura.

Foram testadas concentrações de picloram $(0 ; 2,07$; 4,$14 ; 6,21$ e $\left.8,28 \mu \mathrm{mol} \mathrm{L}^{-1}\right)$ ou $2,4-\mathrm{D}(0 ; 2,26 ; 4,52 ; 6,79$ e $\left.9,05 \mu \mathrm{mol} \mathrm{L}^{-1}\right)$, combinadas com cinetina ( 0 e 0,46 $\mu \mathrm{mol} \mathrm{L}{ }^{-1}$ ), em meio de cultura MS (Murashige \& Skoog, 1962) com metade da concentração de seus sais, suplementado com sacarose (3\%) e solidificado com $0,5 \%$ de ágar $\left(\operatorname{Vetec}^{\circledR}\right)$. $\mathrm{O} \mathrm{pH}$ do meio foi ajustado para $5,8 \pm 0,1$, antes da autoclavagem, a $120{ }^{\circ} \mathrm{C}$ e $1 \mathrm{~atm}$, durante 20 minutos. Após inoculados, os explantes foram mantidos em local escuro, à temperatura de $25 \pm 2{ }^{\circ} \mathrm{C}$ por 30 dias.

A avaliação dos calos foi feita pela atribuição de categorias, cuja escala consistiu em: $0=$ ausência de ca- 
los; 1 = explante intumescido; 2 = início da calogênese; $3=50 \%$ do explante cobertos por calos; $4=$ mais de $50 \%$ do explante cobertos por calos; e $5=$ explante totalmente coberto por calos, segundo metodologia descrita por Carvalho et al. (2014).

$\mathrm{O}$ delineamento experimental foi inteiramente casualizado, em esquema fatorial duplo (auxinas $\mathrm{x}$ cinetina), constituído de 12 repetições por tratamento, sendo cada repetição composta por um explante foliar. Os resultados foram analisados no programa estatístico SAS (SAS Institute, 2004), pela correlação de Spearman, utilizando-se o teste de Kruskal-Wallis e obtendo-se o escore médio de formação de calos.

Utilizaram-se, para análises morfológicas e ultraestruturais, calos oriundos dos tratamentos 2,4-D (6,79 $\mu \mathrm{mol} \mathrm{L}-1) \times$ cinetina $\left(0,46 \mu \mathrm{mol} \mathrm{L}^{-1}\right)$ e picloram $(6,21$ $\mu \mathrm{mol} \mathrm{L}-1) \times$ cinetina $\left(0,46 \mu \mathrm{mol} \mathrm{L} \mathrm{L}^{-1}\right)$.

Os calos foram processados para Microscopia Eletrônica de Transmissão (MET), sendo fixados em glutaraldeído (2,5\%) e paraformaldeído (2,5\%), em tampão cacodilato $0,05 \mathrm{M} \mathrm{pH} \mathrm{7,2} \mathrm{(Karnovsky} \mathrm{modificado),}$ pós-fixados em tetróxido de ósmio a $1 \%$, no mesmo tampão, desidratados em gradiente crescente de acetona. Depois foi feita a inclusão, em série crescente de concentração $(33,66$ e $100 \%$ por duas vezes $)$, de resina Spur, por 4, 8 e 24 horas, respectivamente. Logo em seguida, foram colocados em moldes de silicone em resina pura e secados em estufa, a $70^{\circ} \mathrm{C}$, para a polimerização. Foram feitos cortes em seções semifinas $\left(1 \mu \mathrm{m} \mathrm{L}^{-1}\right)$ [coradas com azul de toluidina ( $1 \mathrm{~g}$ azul de toluidina, $1 \mathrm{~g}$ borato de sódio e $100 \mathrm{~mL}$ de água, purificados em filtro Millipore $0,2 \mu \mathrm{m} \mathrm{L}^{-1}$ ) e montados, permanentemente, em meio Permoult] e ultrafinas $(<100 \mathrm{~nm})$. Os cortes ultrafinos foram coletados em telinhas de cobre de 300 meshs, cobertas com película de formvar e, em seguida, contrastadas em acetato de uranila, seguido por acetato de chumbo, por três minutos cada. As seções foram, em seguida, examinadas em microscópio eletrônico de transmissão Zeiss, modelo EM 902 a $80 \mathrm{Kv}$.

Calos processados para Microscopia Eletrônica de Varredura (MEV) foram fixados em Karnovsky modificado, pós-fixados em tetróxido de ósmio, a 1\%, no mesmo tampão, desidratados em gradiente crescente de acetona, secados em aparelho de ponto crítico com $\mathrm{CO}_{2}$ líquido, montados em "stubs" e metalizados com ouro. As observações foram realizadas em microscópio eletrônico (LEO Evo 040), operando entre 10 e $20 \mathrm{kV}$.

\section{RESULTADOS E DISCUSSÃO}

De maneira geral, a presença de picloram e de cinetina no meio de cultura proporcionou maior formação de calos que a utilização de 2,4-D e cinetina (Figura 1).
Maior formação de calos foi obtida a partir de segmentos foliares cotiledonares, cultivados em meio de cultura suplementado com 4,14 e $8,28 \mu \mathrm{mol} \mathrm{L} \mathrm{L}^{-1}$ de picloram combinado com $0,46 \mu \mathrm{mol} \mathrm{L}^{-1}$ de cinetina, com escore médio de 1 (Figura 1). A calogênese de segmentos foliares cultivados em meio com ausência de picloram, independentemente de cinetina, alcançou escore médio de 0,31 e 0,25. A adição do regulador 2,4-D, na concentração de $6,79 \mu \mathrm{mol} \mathrm{L} \mathrm{L}^{-1}$, combinada com 0,46 $\mu \mathrm{mol} \mathrm{L} \mathrm{L}^{-1}$ de cinetina, resultou em baixa formação de calos (escore médio de 0,56 ).

O suprimento exógeno de reguladores de crescimento ao meio de cultura é, em muitos casos, necessário para a calogênese (Chain Jardim Rosa \& Dornelas, 2012; Pêgo et al., 2013). Estudos realizados com a espécie nativa Passiflora foetida foram eficientes em produzirem calos em meio de cultura MS com 2,4-D e cinetina (Rasool et al., 2011). Esses resultados confirmam que a interação entre auxinas e citocininas é, muita das vezes, responsável pela alta indução de calos. Entretanto, estudos realizados em diversas espécies, como Passiflora alata (maracujá-doce) (Pacheco et al., 2012), Passiflora suberosa (maracujá-de-cortiça) (Garcia et al., 2011) e Passiflora spp. (Chaim Jardim Rosa et al., 2015) confirmaram que alta proliferação de calos pode também ser obtida em meio de cultura com somente um tipo de regulador de crescimento, como a auxina picloram ou o 2,4-D.

As observações em MEV mostraram que a proliferação de células dos calos cultivados em meio de cultura com 2,4-D e cinetina apresentou-se bem organizada, com células de formato isodiamétrico (Figura 2a). No entanto, na superfície dos calos cultivados em meio contendo picloram e cinetina foram verificadas, principalmente, formas alongadas (Figura 2b).

Observações em MET, dos calos cultivados na presença de 2,4-D e cinetina, mostraram que as células são pequenas, apresentam disposição compacta, (Figura 3a), com pequeno espaço intercelular (Figura 3c). O citoplasma é denso e abundante, com mitocôndrias, de formato arredondado com cristas bem desenvolvidas e retículo endoplasmático (Figura 3d). Os vacúolos apresentaram dimensões variadas, sendo que os maiores ocuparam posição central na célula (Figura 3b). Pôde-se observar também a presença de corpos lipídicos dispersos no citoplasma (Figura 3a,c), grãos de amido e provável acúmulo de compostos fenólicos (Figura 3a).

Células dos calos cultivados na presença de picloram e cinetina, observadas em MET, são grandes, com espaços intercelulares e de formato irregular (Figura 4a). Seu citoplasma, de forma semelhante ao das anteriores, contém muitas organelas, como mitocôndrias de formato alongado (Figura 4b), retículo endoplasmático (Figura 
4c) e plastídeos conspícuos com grãos de amido (Figura 4c). As células apresentaram um grande vacúolo, vesículas provavelmente oriundas do retículo endoplasmático (Figura 4d) e corpos lipídicos (Figura 4b), porém, não foi observado acúmulo de compostos fenólicos.

Células podem- se tornar competentes para embriogênese somática, desde que a interação entre fatores endógenos e exógenos, como a concentração e o tipo de regulador de crescimento utilizado, esteja balanceada, desencadeando uma série de eventos moleculares que podem afetar a expressão do gene e determinar a diferenciação de embriões somáticos (Nolan et al., 2014). A adição de auxinas exógenas ao meio de cultura pode aumentar a totipotência de células com habilidade para proliferar e regenerar embriões somáticos (Garcia et al., 2011).

Células embriogênicas são normalmente caracterizadas por apresentarem pequeno tamanho, grande núcleo com nucléolos proeminentes, citoplasma denso com numerosos ribossomos, mitocôndria e plastídeos com

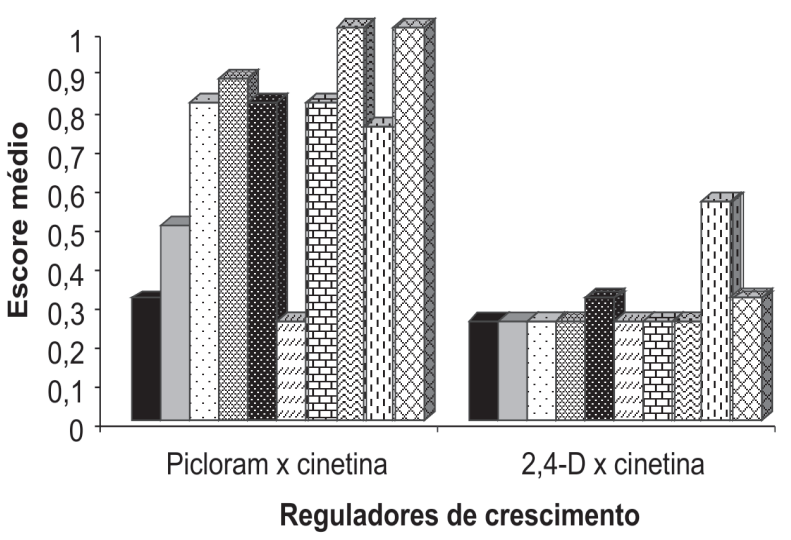

\begin{abstract}
Dicloram $0 \mu \mathrm{mol} \mathrm{L}{ }^{-1} \mathrm{x}$ cinetina $0 \mu \mathrm{mol} \mathrm{L} \mathrm{L}^{-1} ; 2,4-\mathrm{D} 0 \mu \mathrm{mol} \mathrm{L} \mathrm{L}^{-1} \mathrm{x}$ cinetina $0 \mu \mathrm{mol} \mathrm{L} \mathrm{L}^{-1}$

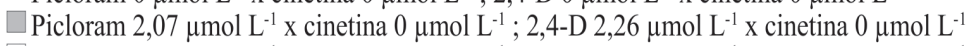

$\therefore$ Picloram 4,14 umol L-1 $\mathrm{x}$ cinetina $0 \mu \mathrm{mol} \mathrm{L}^{-1} ; 2,4-\mathrm{D} 4,52 \mu \mathrm{mol} \mathrm{L}^{-1} \mathrm{x}$ cinetina $0 \mu \mathrm{mol} \mathrm{L}{ }^{-1}$

兹 Picloram 6,21 $\mu \mathrm{mol} \mathrm{L}^{-1} \mathrm{x}$ cinetina $0 \mu \mathrm{mol} \mathrm{L}^{-1}$; 2,4-D 6,79 $\mu \mathrm{mol} \mathrm{L}^{-1} \mathrm{x}$ cinetina $0 \mu \mathrm{mol} \mathrm{L}^{-1}$

Picloram 8,28 $\mu \mathrm{mol} \mathrm{L}^{-1} \mathrm{x}$ cinetina $0 \mu \mathrm{mol} \mathrm{L}^{-1}$; 2,4-D 9,05 $\mu \mathrm{mol} \mathrm{L}^{-1} \mathrm{x}$ cinetina $0 \mu \mathrm{mol} \mathrm{L}^{-1}$

Picloram $0 \mu \mathrm{mol} \mathrm{L}-1 \mathrm{x}$ cinetina $0,46 \mu \mathrm{mol} \mathrm{L}^{-1} ; 2,4-\mathrm{D} 0 \mu \mathrm{mol} \mathrm{L}^{-1} \mathrm{x}$ cinetina $0,46 \mu \mathrm{mol} \mathrm{L}^{-1}$

⿷ Picloram 2,07 $\mu \mathrm{mol} \mathrm{L}{ }^{-1} \mathrm{x}$ cinetina $0,46 \mu \mathrm{mol} \mathrm{L} \mathrm{L}^{-1} ; 2,4-\mathrm{D} 2,26 \mu \mathrm{mol} \mathrm{L}^{-1} \mathrm{x}$ cinetina $0,46 \mu \mathrm{mol} \mathrm{L}-1$

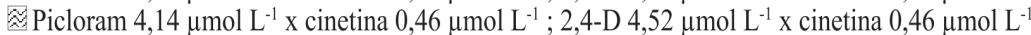

Picloram 6,21 $\mu \mathrm{mol} \mathrm{L}^{-1} \mathrm{x}$ cinetina $0,46 \mu \mathrm{mol} \mathrm{L}^{-1} ; 2,4-\mathrm{D} 6,79 \mu \mathrm{mol} \mathrm{L}^{-1} \mathrm{x}$ cinetina $0,46 \mu \mathrm{mol} \mathrm{L}^{-1}$

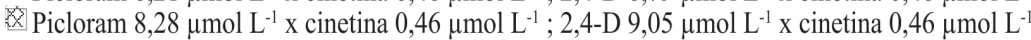

Figura 1. Indução de calos em segmentos foliares cotiledonares de Passiflora gibertii em meio de cultura MS, contendo metade da concentração de seus sais e suplementado com diferentes tipos, concentrações e combinações de reguladores de crescimento, aos 30 dias de cultivo in vitro.
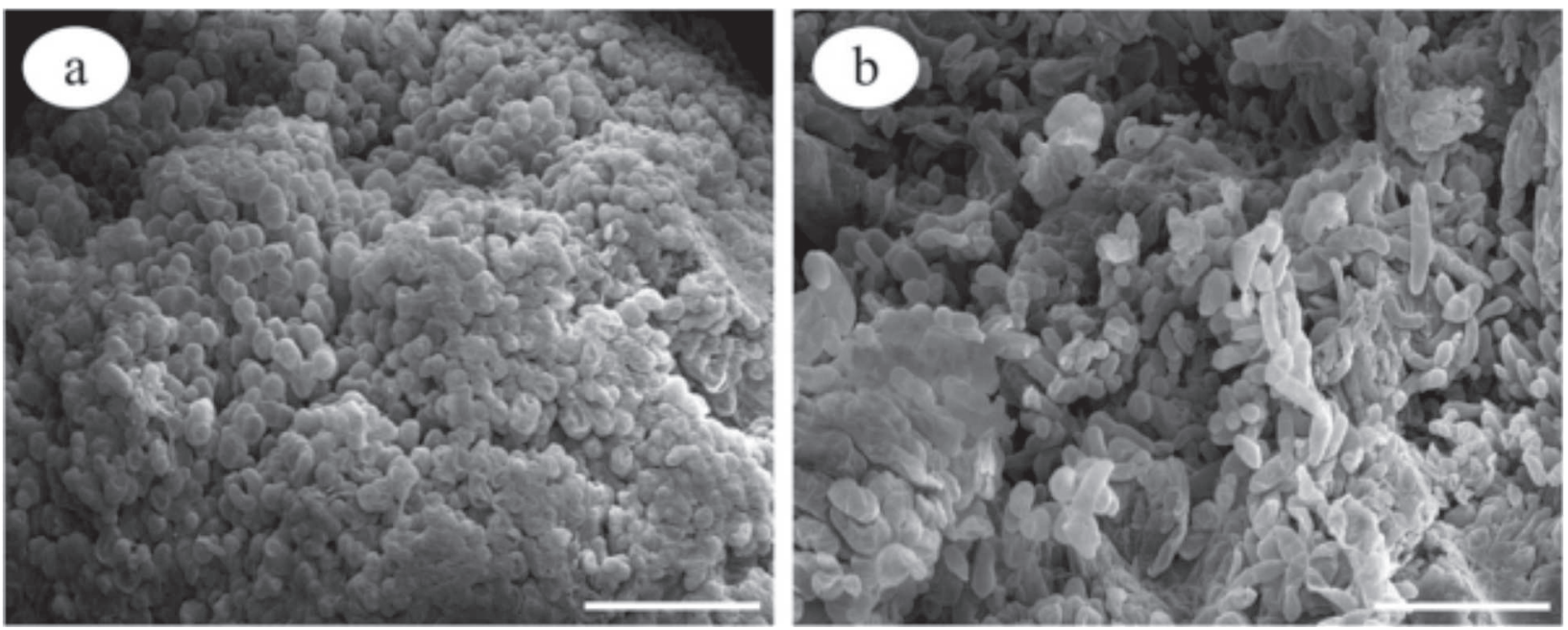

Figura 2. Eletromicrografias de varredura de calos, aos 30 dias de cultivo in vitro, oriundos de folhas cotiledonares de Passiflora gibertii e cultivados em meio de cultura MS, contendo metade da concentração de seus sais e suplementado com: 2,4-D e cinetina, evidenciando células isodiamétricas (a); picloram e cinetina evidenciando, na sua maioria, células alongadas (b). Barras $=100 \mu \mathrm{m}$. 

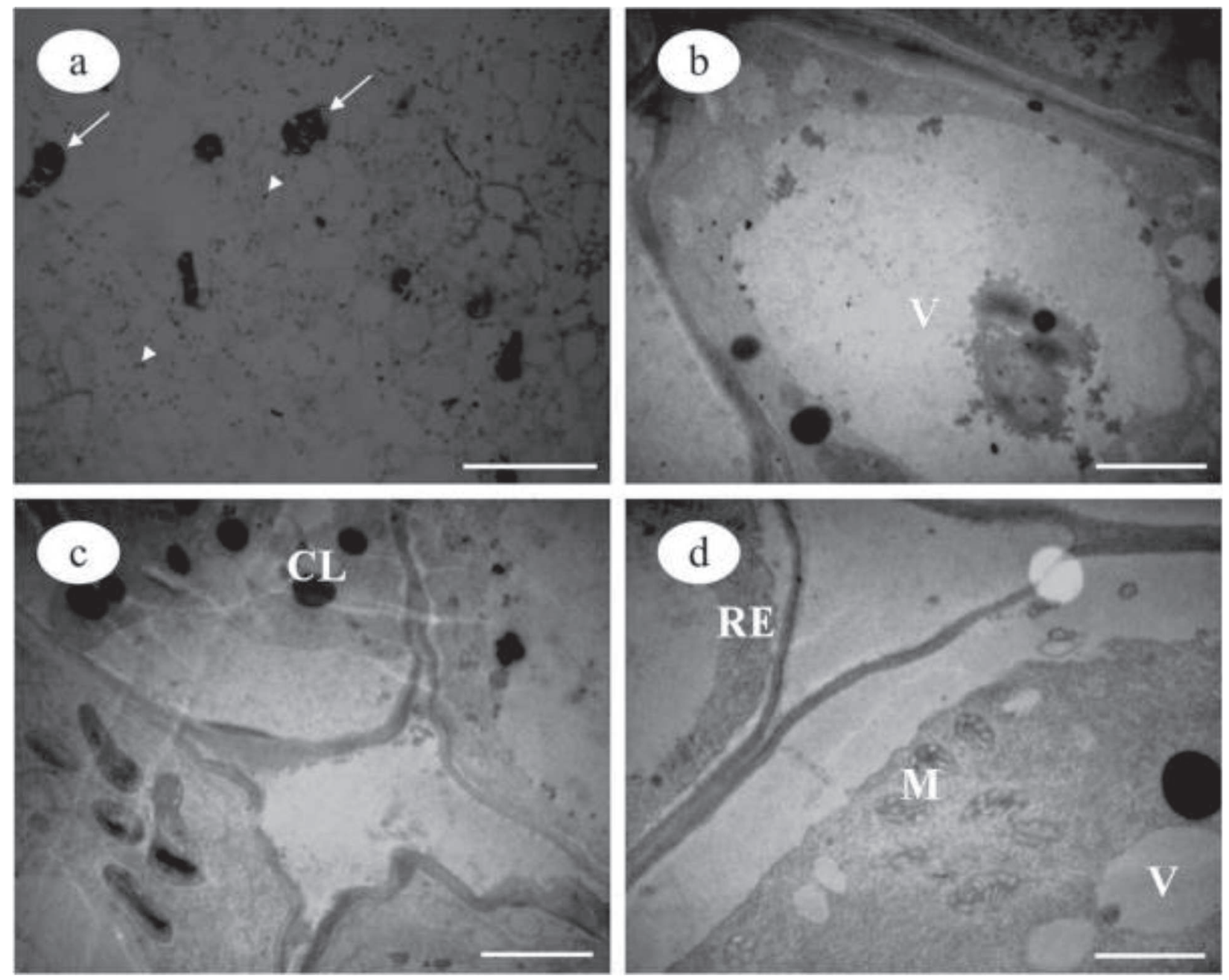

Figura 3. Fotomicrografia (a) e eletromicrografias de transmissão (b-d) de células dos calos, aos 30 dias de cultivo in vitro, oriundos de folhas cotiledonares de Passiflora gibertii e cultivados em meio de cultura MS, contendo metade da concentração de seus sais e suplementado com 2,4-D e cinetina. Células com acúmulo de compostos fenólicos (setas) e grãos de amido (pontas de seta) (a). Citoplasma com mitocôndrias (M), retículo endoplasmático (RE) e corpos lipídicos (CL) dispersos; notar vacúolos (V) com diferentes formas e dimensões. Barras $=50 \mu \mathrm{m}(\mathrm{a}), 2 \mu \mathrm{m}(\mathrm{b}, \mathrm{c}), 1 \mu \mathrm{m}(\mathrm{d})$.

amido. Mitocôndrias dessas células são abundantes, usualmente ovais ou arredondadas e apresentam uma matriz eletrodensa com a crista bem desenvolvida (Appezzatoda-Glória \& Machado, 2004; Pinto et al., 2011), como as observadas, neste trabalho, em células de calos cultivados em meio com 2,4-D e cinetina. Essas características são típicas de intensa atividade metabólica, graças às altas taxas respiratórias. Células não embriogênicas são caracterizadas por apresentarem formato alongado, com mitocôndria alongada, núcleo pequeno, citoplasma menos denso e grande vacúolo (Silva et al., 2009; Pinto et al., 2011), características também observadas, neste estudo, porém, em células de calos cultivados na presença de picloram e cinetina.

Calos embriogênicos de Passiûora cincinnata (maracujazeiro-do-mato) (Silva et al., 2009; Pinto et al., 2010) e de Passiflora edulis (maracujazeiro amarelo- azedo) (Pinto et al., 2011; Rocha et al., 2015) foram obtidos em meio de cultura com 2,4-D e benziladenina (BA), confirmando o grande potencial embriogênico dos calos de $P$. gibertii obtidos, neste estudo, com adição dos reguladores de crescimento 2,4-D e cinetina, para posterior regeneração de plântulas.

Os resultados apresentados neste estudo, referentes à indução de calos oriundos de explantes foliares de Passiflora gibertii e à caracterização morfológica e ultraestrutural de suas células, demonstraram a possibilidade de obtenção de células com características necessárias para competência embriogênica. Trabalhos futuros deverão ser realizados, a fim de avaliar se as células de calos de $P$. giberti, $i$ cultivadas nas condições estudadas, com 2,4-D e cinetina, e que apresentaram características embriogênicas, diferenciar-se-ão em embriões somáticos e, posteriormente, em plântulas. 

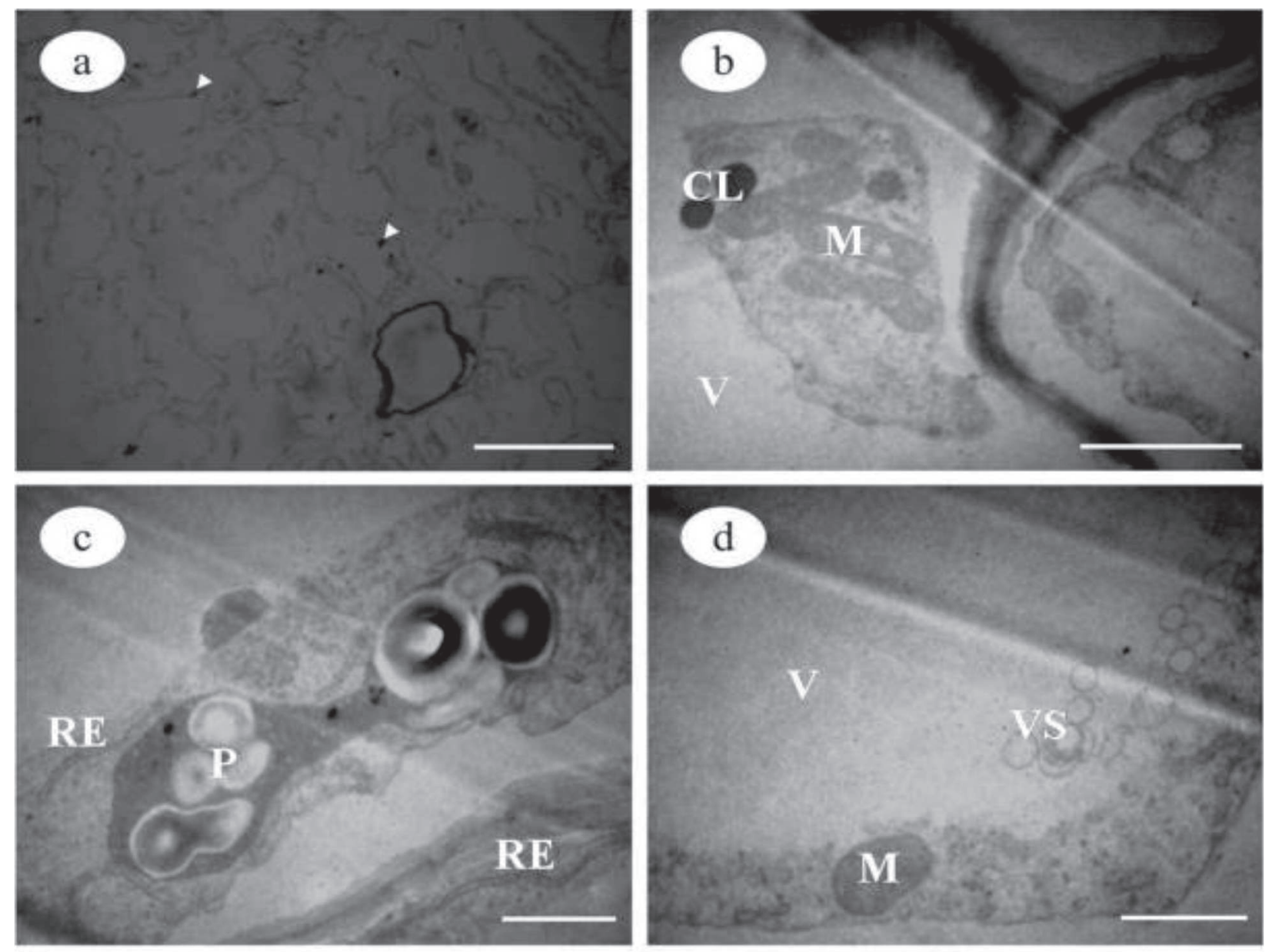

Figura 4. Fotomicrografia (a) e eletromicrografias de transmissão (b-d) de células dos calos, aos 30 dias de cultivo in vitro, oriundos de folhas cotiledonares de Passiflora gibertii e cultivados em meio de cultura MS, contendo metade da concentração de seus sais e suplementado com picloram e cinetina. Células com acúmulo de grãos de amido (pontas de seta) (a). Citoplasma com mitocôndrias (M), retículo endoplasmático (RE), corpos lipídicos (CL), vesículas secretoras (VS) e plastídeos (P) conspícuos com grãos de amido. Notar vacúolos (V) com numerosas vesículas secretoras (b-d). Barras = $50 \mu \mathrm{m}$ (a), $2 \mu \mathrm{m}$ (b), $1 \mu \mathrm{m}$ (c,d).

\section{CONCLUSÕES}

A adição de picloram e de cinetina ao meio de cultura promove maior formação de calos, em explantes foliares de $P$. gibertii, que 2,4-D e cinetina.

O regulador 2,4-D proporciona a obtenção de calos com células de formato isodiamétrico, pequenas e com pequeno espaço intercelular, sistema celular organizado e predominância de mitocôndrias de formato arredondado.

Com a utilização do regulador de crescimento picloram, observa-se a predominância de células grandes e de formato alongado, de espaços intercelulares, de sistema celular desorganizado e de mitocôndrias de formato alongado.

\section{AGRADECIMENTOS}

Este trabalho foi financiado pela Fundação de Amparo à Pesquisa do Estado de Minas Gerais (FAPEMIG), pela Coordenação de Aperfeiçoamento de Pessoal de Nível Superior (CAPES) e pelo Conselho Nacional de Desenvolvimento Científico e Tecnológico (CNPq).

\section{REFERÊNCIAS}

Aguiar AVM, Silva RM, Cardoso EA, Maracajá PB \& Pires H (2010) Utilização de espécies de Passiflora spp. como porta-enxertos no controle de doenças do maracujazeiro. Agropecuária Científica no Semi-Árido, 6:17-22.

Appezzato-da-Glória B \& Machado SR (2004) Ultrastructural analysis of in vitro direct and indirect organogenesis. Revista Brasileira de Botânica, 27:429-437.

Carvalho MAdF, Paiva R, Alves E, Nogueira RC, Stein VC, de Castro EM, de Oliveira Paiva PD \& Vargas DP (2013) Morphogenetic potential of native passion fruit (Passiflora gibertii N. E. Brown.) calli. Brazilian Journal of Botany, 36:141-151.

Carvalho MAdF, Paiva R, Stein VC, Herrera RC, Porto JMP, Vargas DP \& Alves E (2014) Induction and morpho-ultrastructural analysis of organogenic calli of a wild passionfruit. Brazilian Archives of Biology and Technology, 57:851-859.

Rev. Ceres, Viçosa, v. 62, n.4, p. 340-346, jul-ago, 2015 
Chain Jardim Rosa YB \& Dornelas MC (2012) In vitro plant regeneration and de novo differentiation of secretory trichomes in Passiflora foetida L. (Passifloraceae). Plant Cell Tissue and Organ Culture, 108:91-99.

Chaim Jardim Rosa YB, Monte Bello CC \& Dornelas MC (2015) Speciesdependent divergent responses to in vitro somatic embryo induction in Passiflora spp. Plant Cell Tissue and Organ Culture, 120:69-77.

Corredoira E, Ballester A, Ibarra M \& Vieitez AM (2015) Induction of somatic embryogenesis in explants of shoot cultures established from adult Eucalyptus globulus and E. saligna $\times$ E. maidenii trees. Tree Physiology, 35:678-690.

Cunha MAP, Barbosa LV \& Junqueira NTV (2002) Espécies de maracujazeiro. In: Lima AA (Ed.) Maracujá produção: Aspectos técnicos. Brasília, Embrapa Informação Tecnológica. p.15-24.

Garcia R, Pacheco G, Falcão E, Borges G \& Mansur E (2011) Influence of type of explant, plant growth regulators, salt composition of basal medium, and light on callogenesis and regeneration in Passiflora suberosa L. (Passifloraceae). Plant Cell, Tissue and Organ Culture, 106:47-54.

Murashige T \& Skoog F (1962) A revised medium for rapid growth and bioassays with tobacco tissue cultures. Physiologia Plantarum, 15:473-497.

Nolan KE, Song Y, Liao S, Saeed NA, Zhang X \& Rose RJ (2014) An unusual abscisic acid and gibberellic acid synergism increases somatic embryogenesis, facilitates its genetic analysis and improves transformation in Medicago truncatula. Plos One, 9:1-8.

Pacheco G, Garcia R, Lugato D, Vianna M \& Mansur E (2012) Plant regeneration, callus induction and establishment of cell suspension cultures of Passiflora alata Curtis. Scientia Horticulturae, 144:42-47.

Pêgo RG, Paiva PDO \& Paiva R (2013) Micropropagation of Syngonanthus elegantulus. Ciência \& Agrotecnologia, 37:32-39.

Pinto DLP, Almeida AMR, Rêgo MM, Silva ML, Oliveira EJ \& Otoni WC (2011) Somatic embryogenesis from mature zygotic embryos of commercial passionfruit (Passiflora edulis Sims) genotypes. Plant Cell, Tissue and Organ Culture, 107:521-530.
Pinto DLP, Barros BA, Viccini LF, Campos JMS, Silva ML \& Otoni WC (2010) Ploidy stability of somatic embryogenesis-derived Passiflora cincinnata Mast. plants as assessed by flow cytometry. Plant Cell, Tissue and Organ Culture, 103:71-79.

Rasool SN, Jaheerunnisa S, Jayaveera KN \& Suresh Kumar C (2011) In vitro callus induction and in vivo antioxidant activity of Passiflora foetida L. leaves. International Journal of Applied Research in Natural Products, 4:1-10.

Reis LB, Silva ML, Lima ABP, Oliveira MLP, Pinto DLP, Lani ERG \& Otoni WC (2007) Agrobacterium rhizogenes-mediated transformation of passionfruit species: Passiflora cincinnata and P. edulis f. flavicarpa. Acta Horticulturae, 738:425-431.

Rocha DI, Monte-Bello CC \& Dornelas MC (2015) Alternative induction of de novo shoot organogenesis or somatic embryogenesis from in vitro cultures of mature zygotic embryos of passion fruit (Passiflora edulis Sims) is modulated by the ratio between auxin and cytokinin in the medium. Plant Cell Tissue and Organ Culture, 120:1087-1098.

Santana JRF, Paiva R, Souza AV \& Oliveira LM (2011) Effect of different carbon sources on the in vitro multiplication of Annona sp. Ciência \& Agrotecnologia, 35:487-493.

SAS Institute Inc. (2004) Statistical Analysis System user's guide. Version 9.1.3. Cary, Statistical Analysis System Institute. 846p.

Silva ML, Pinto DLP, Guerra MP, Floh EIS, Bruckner CH \& Otoni WC (2009) A novel regeneration system for a wild passion fruit species (Passiflora cincinnata Mast.) based on somatic embryogenesis from mature zygotic embryos. Plant Cell, Tissue and Organ Culture, 99:4754.

Silvia MC, Vieira MLC, Mondin M \& Aguiar-Perecin MLR (2005) Comparative karyotype analysis of three Passiflora L. species and cytogenetic characterization of somatic hybrids. Caryologia, 58:220228.

Soares WS, Rêgo MM, Rêgo ER, Barroso PA, Nascimento KS \& Ferreira KT (2012) Estabelecimento in vitro e micropropagação de maracujá silvestre (Passiflora foetida L.). Revista Brasileira de Plantas Medicinais, $14: 138-142$ 